\title{
The conserved upstream region of $I s C B / C$ determines expression of different levansucrase genes in plant pathogen Pseudomonas syringae
}

\author{
Shaunak Khandekar ${ }^{1 *}$, Abhishek Srivastava ${ }^{1,2}$, Daniel Pletzer ${ }^{1}$, Antje Stahl $^{1}$ and Matthias S Ullrich ${ }^{1}$
}

\begin{abstract}
Background: Pseudomonas syringae pv. glycinea PG4180 is an opportunistic plant pathogen which causes bacterial blight of soybean plants. It produces the exopolysaccharide levan by the enzyme levansucrase. Levansucrase has three gene copies in PG4180, two of which, IsCB and IsCC, are expressed while the third, IsCA, is cryptic. Previously, nucleotide sequence alignments of $I s C B / C$ variants in various $P$. syringae showed that a $\sim 450$-bp phage-associated promoter element (PAPE) including the first 48 nucleotides of the ORF is absent in IsCA.

Results: Herein, we tested whether this upstream region is responsible for the expression of IsCB/C and IscA. Initially, the transcriptional start site for I $I C B / C$ was determined. A fusion of the PAPE with the ORF of I $S C A(I s C B \cup p N A)$ was generated and introduced to a levan-negative mutant of PG4180. Additionally, fusions comprising of the non-coding part of the upstream region of $I s C B$ with $I s C A\left(I s c B_{\cup p} A\right)$ or the upstream region of $I s C A$ with $I s c B\left(I s C A_{\cup p} B\right)$ were generated. Transformants harboring the $I s \subset B_{\cup p N} A$ or the $I s c B_{U p} A$ fusion, respectively, showed levan formation while the transformant carrying $I s A_{U p} B$ did not. qRT-PCR and Western blot analyses showed that IsCB $B_{\cup p N} A$ had an expression similar to $I s c B$ while IscBup $A$ had a lower expression. Accuracy of protein fusions was confirmed by MALDI-TOF peptide fingerprinting.
\end{abstract}

Conclusions: Our data suggested that the upstream sequence of $I s c B$ is essential for expression of levansucrase while the $\mathrm{N}$-terminus of LscB mediates an enhanced expression. In contrast, the upstream region of IscA does not lead to expression of $I s C B$. We propose that I $s \subset A$ might be an ancestral levansucrase variant upstream of which the PAPE got inserted by potentially phage-mediated transposition events leading to expression of levansucrase in $P$. syringae.

Keywords: Pseudomonas syringae, Levansucrase, Expression, Exopolysaccharides, Levan, Evolution

\section{Background}

Pseudomonas syringae comprises a large and well-studied group of plant-pathogenic bacteria [1]. They infect a broad range of host plants and are subdivided into more than 50 different pathogenic variants called pathovars [2]. $P$. syringae possesses a number of well-studied virulence and pathogenicity factors such as the Type III effector trafficking system, various phytotoxins, different mechanisms suppressing the plant defense, or synthesis of exopolysaccharides [3-5]. Exopolysaccharides play a variety of roles in virulence and pathogenicity not only in Pseudomonas but also in other biofilm-producing organisms [6,7]. The two major exopolysaccharides produced

\footnotetext{
* Correspondence: skhandekar@jacobs-alumni.de

1 Molecular Life Sciences Research Center, Jacobs University Bremen, Campus Ring 1, Bremen 28759, Germany

Full list of author information is available at the end of the article
}

by $P$. syringae pv. glycinea are alginate and levan [7]. Levan is a $\beta-(2,6)$ polyfructan with extensive branching through $\beta-(2,1)$ linkages, while alginate is a copolymer of O-acetylated $\beta$-(1,4)-linked D-mannuronic acid and its C-5 epimer, L-guluronic acid [7-10].

P. syringae pv. glycinea PG4180 causes bacterial blight of soybean plants. Like some other Pseudomonas species, this organism utilizes sucrose as a carbon source with the help of the enzyme levansucrase (EC 2.4.1.10, Lsc), in the process releasing glucose and forming the exopolysaccharide levan. PG4180 produces no alginate due to a native frameshift mutation in the $\operatorname{alg} T$ gene and hence, the exopolysaccharide matrix of this strain is mainly composed of levan [11]. Additionally to several draft genome sequences [12-18], the complete genome sequences of three P. syringae pathovars are available, namely pv. tomato DC3000 [19], pv. phaseolicola 1448A [20] and pv. syringae B728a 
[21]. These strains serve as excellent model organisms to study plant-microbe interactions. Like in some other $P$. syringae pathovars, the PG4180 genome contains three copies of the $l s c$ gene, of which two $-l s c A$ and $l s c C$ - are chromosomally encoded while $l s c B$ is plasmidencoded. Of the three copies, only $l s c B$ and $l s c C$ have been shown to be expressed while no expression was observed for $l s c A$ under the tested growth conditions since a mutant, PG4180.M6, lacking $l s c B$ and $l s c C$ but containing $l s c A$ was levan-negative [10]. Interestingly, the ORF coding for LscA is fully functional since this gene from pv. glycinea, and its homologues from pv. phaseolicola and pv. tomato, could be expressed from recombinant promoters in Escherichia coli $[9,22]$. Even though LscB is predominantly extra-cellular and $\mathrm{LscC}$ is predominantly retained in the periplasm, the two enzymes are $98 \%$ identical at the amino acid level [23]. There are only five amino acid residues different, four of which are conserved changes. Since the enzymes are highly similar in their structure as well as function, all experiments in this study were done using $l s c B$ only.

As reported by Srivastava et al. [24], nucleotide sequence comparison of the $l s c A$ variants with those of $l s c B / C$ variants of $P$. syringae pathovars showed that the first 48 -bp of the N-terminus of the ORF $l s c B / C$ were absent in lscA. In silico removal of this $\mathrm{N}$-terminal region increased the identity from $87.5 \%$ to $93 \%$ at the amino acid residue sequence level between LscA and B/C variants. The comparison also showed that a $\sim 450$-bp upstream region, which is highly conserved in all $l s c B / C$ variant loci, is missing upstream of $l s c A$. This region spanning from -450 -bp to +48 -bp with respect to the translational start site of $l s c B / C$ was predicted to be a pro-phage borne DNA based on sequence similarities and hence was termed phage-associated promoter element (PAPE) [24].

P. syringae is the only Lsc-synthesizing organism having multiple gene copies coding for this enzyme. The rationale for the occurrence of multiple $l s c$ gene copies, some of which carry upstream PAPEs, remained obscure and prompted the current study, during which the transcriptional start site of $l s c B / C$ was determined to be -339 bp upstream to the translational start codon. Subsequently, the PAPE with or without the $\mathrm{N}$-terminal coding sequence was fused to $l s c A$. Additionally, the upstream region of $l s c A$ was fused with the coding sequence of $l s c B$ while $l s c B$ and $l s c A$ with their native upstream sequences served as controls. All fusion constructs were expressed in the levan-negative mutant PG4180.M6 [10], and tested for their levan formation ability by zymographic detection followed by matrix-assisted laser desorption/ionization time of flight (MALDI-TOF) analysis as well as by Western blotting. Furthermore, the expression of the fusions at the mRNA level was checked by qRT-PCR analysis. In addition, a PCR approach with cDNA was undertaken to show that the expression of $l s c A$ is also cryptic in other $P$. syringae pathovars.

\section{Results}

\section{Determination of the transcriptional start site of $I s C B$}

The coding regions and upstream sequences of $l s c B / C$ are highly identical to each other $(98.1 \%$ DNA identity for the coding sequences and 97.5\% DNA identity for the 500-bp upstream sequences). As shown by Srivastava et al., a deletion construct ending at position -332-bp with respect to the $l s c B$ translational start codon does not lead to levan formation in levan negative mutant PG4180.M6 while the construct ending -440-bp leads to levan formation in the same mutant [24]. Consequently, primer extension experiments using total RNA from PG4180 cells and a set of reverse oligonucleotide primers were used to determine the transcriptional start site (TSS) of the $l s c B$ gene. Resolving the extension products on a polyacrylamide gel resulted in a clear signal at nucleotide position -339-bp upstream of the translational start codon of $l s c B$ (Figure 1). The experiments were repeated for $l s c C$ giving identical results (Data not shown).

\section{Qualitative analysis of Isc fusion proteins}

The fusion constructs were introduced to the levannegative mutant PG4180.M6 and were first analyzed

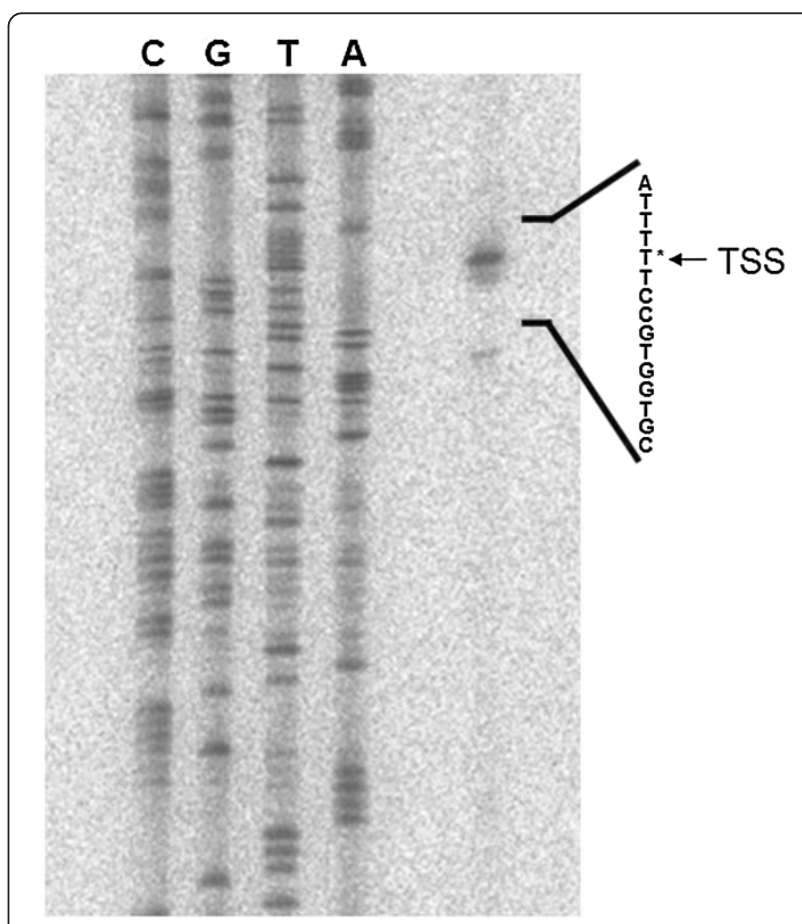

Figure 1 Determination of the transcriptional start site (TSS) of IsCB in P. syringae pv. glycinea PG4180. The TSS was determined by electrophoresis of nucleotide sequencing reaction and primer extension product using primer pe.BC.PG $150 \mathrm{bp}$ on $6 \%$ polyacrylamide gel. Nucleotide of the TSS (*) is shown at the right. 
for their levan forming ability on sucrose supplemented mannitol-glutamate agar plates. Both, the PG4180.M6 mutant complemented with $l s c B_{U p N} A$ and $l s c B_{U p} A$, showed levan formation indistinguishable from that of the PG4180. M6 mutant complemented with $l s c B$ (Figure 2). In contrast, PG4180.M6 complemented with $l s c A_{U p} B$ was levan negative, same as PG4180.M6 transformed with $l s c A$, thus, suggesting that the upstream region of $l s c B$ mediates expression of downstream located genes while that of $l s c A$ does not.

\section{Characterization of Isc fusion proteins}

To verify the molecular sizes of Lsc encoded by the individual fusion constructs, a Western blot analysis using Lsc-specific antibodies was performed (Figure 3a). Under denaturing conditions, it was interesting to observe that ${ }_{\text {Lsc }} \mathrm{B}_{\mathrm{UpN}} \mathrm{A}$ migrated at an intermediate rate i.e. faster than $\mathrm{LscB}$ but slower than $\operatorname{LscB}_{\mathrm{Up}} \mathrm{A}$. The signal for $\mathrm{LscB}_{\mathrm{Up}} \mathrm{A}$ was weaker than those representing $\mathrm{LscB}$ or ${ }_{\text {LscB }} \mathrm{B}_{\mathrm{UpN}} \mathrm{A}$ suggesting that the N-terminus of LscB might contribute to the expression level or stability of Lsc. In contrast, protein samples of PG4180.M6 transformed with LscA or $\operatorname{Lsc}_{U \mathrm{p}} \mathrm{B}$ did not show any signal specific for Lsc at all thus confirming that lack of levan formation was due to lack of the corresponding protein.

To check for the enzymatic function of Lscs encoded by the individual fusion constructs, zymographic detection was done with non-denatured total protein samples of transformed mutants (Figure $3 \mathrm{~b}$ ). The above reported levan

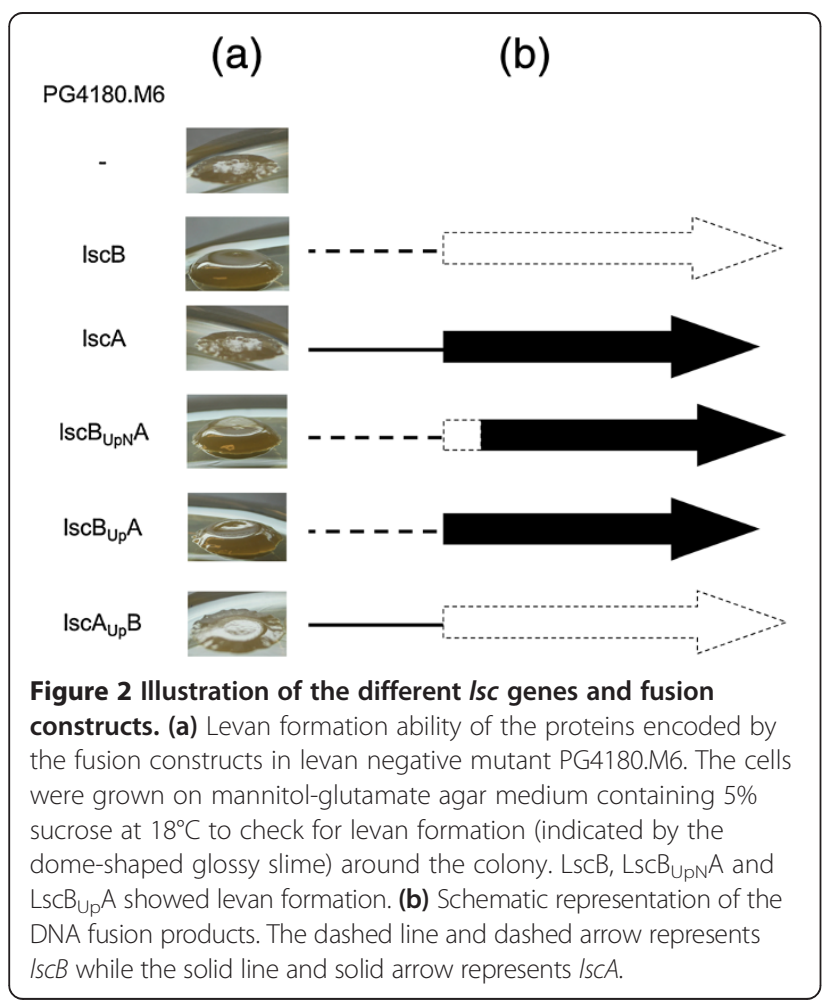

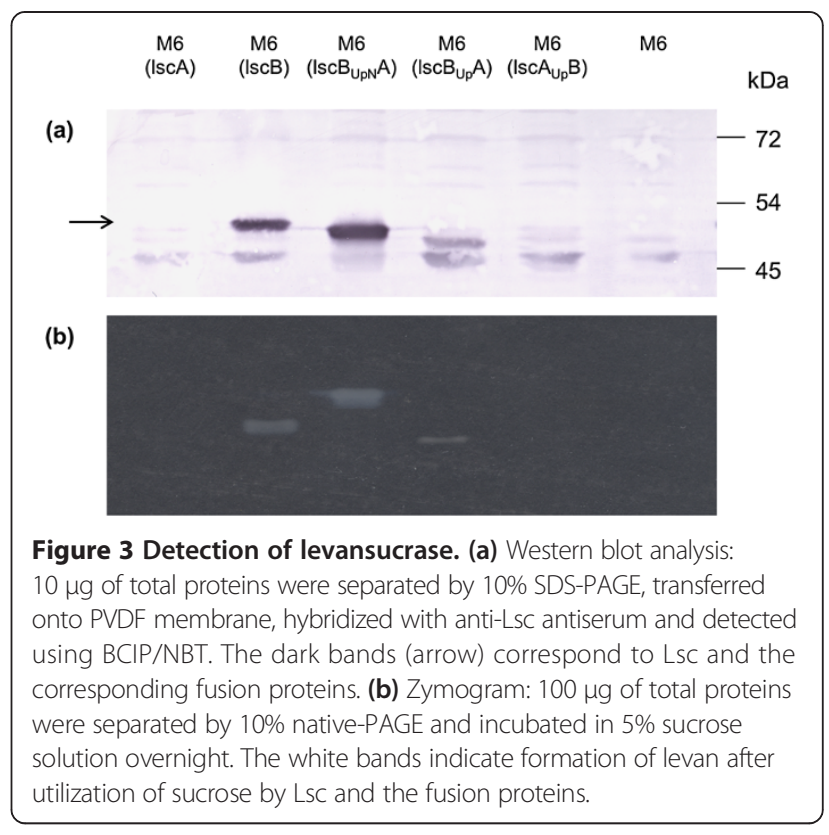

forming ability of transformants $\mathrm{M} 6(\mathrm{lscB}), \mathrm{M} 6\left(\mathrm{lsc}_{\mathrm{UpN}} \mathrm{A}\right)$ and $\mathrm{M} 6\left(\mathrm{lscB}_{\mathrm{Up}} \mathrm{A}\right)$ could be attributed to the enzymatic functioning of proteins or fusion proteins. As expected, native protein samples derived from M6(lscA) or M6 $\left(\operatorname{lsc}_{U_{p}} \mathrm{~B}\right)$ did not exhibit any in-gel levan production (Figure $3 \mathrm{~b}$ ). An interesting observation was the altered electrophoretic mobility of the enzymatically active proteins. The $\mathrm{LscB}_{\mathrm{UpN}} \mathrm{A}$ migrated slower as compared to $\mathrm{LscB}$ even though the predicted molecular masses of both proteins were almost identical $(\sim 47.6 \mathrm{kDa})$ suggesting possible differences in the respective protein charges. In accordance with the Western blot results, $\operatorname{LscB}_{U \mathrm{Up}} \mathrm{A}$ seemed to be less expressed than $\mathrm{LscB}$ or $\mathrm{LscB}_{\mathrm{UpN}} \mathrm{A}$ suggesting an important role of the $\mathrm{N}$-terminus for transcriptional or translational processes.

\section{MALDI-TOF analysis}

The altered electrophoretic migration rate of $\mathrm{LscB}_{\mathrm{UpN}} \mathrm{A}$ as compared to LscB during the native gel protein separation suggested that the two proteins were indeed different although their predicted protein sizes were almost identical. To demonstrate that $\mathrm{LscB}_{\mathrm{UpN}} \mathrm{A}$ produced a unique and novel enzyme and to show that the other two transformants indeed also produced the intended Lsc proteins, we subjected the levan-forming fusion proteins to MALDITOF analysis. The peptides recovered in the MALDI-TOF analysis are shown in Figure 4. The recovered peptides gave rise to an overall good coverage in the protein sequences (Table 1). Some of the peptides recovered were unique to each protein (Figure 4, underlined). E.g., peptides SFVQEVYDYGYIPAM from LscB $\mathrm{BpN}_{\mathrm{Up}} \mathrm{A}$ and SFVQEEYDYGYIPAM from LscB were located at the same position, namely 413-427, in the respective amino acid sequences 
of these proteins but had different masses, 1,782 $\mathrm{Da}$ as compared to $1,812 \mathrm{Da}$, indicating they were from different proteins. Similar differences were observed for the other peptide sequences shown in the Figure 4 indicating that the fusion constructs indeed led to the synthesis of novel fusion proteins or of the proteins intended despite the presence of similar upstream regions.

\section{Analysis of IscA fusion protein expression by qRT-PCR}

The difference in the amount of levan produced by $\operatorname{LscB}_{\mathrm{Up}} \mathrm{A}$ as compared to $\mathrm{LscB}_{\mathrm{UpN}} \mathrm{A}$ and $\mathrm{LscB}$ in the zymogram prompted us to check if this correlated at the RNA level. Samples were grown in $\mathrm{HSC}$ medium at $18^{\circ} \mathrm{C}$ and harvested at $\mathrm{OD}_{600}$ of 0.5 since $l s c$ transcription is maximum at this optical density [23]. The total RNA was extracted from the cells and the expression of $l s c B$ and $l s c A_{U p} B$ was checked by $l s c B$-specific primers while that of $l s c A, l s c B_{U p N} A$ and $l s c B_{U p} A$ was checked by $l s c A$-specific primers. The results showed that, considering the standard deviation obtained for the samples, the $l s c B_{U p N} A$ had expression levels similar to $l s c B$ (Figure 5) further supporting the results of the
Western blot and zymogram. On the other hand $l s c B_{U p} A$ had only $60 \%$ expression as compared to $l s c B$. As was the trend seen in the Western blot and zymogram, $l s c A$ and $l s c A_{U p} B$ had no expression. This indicated that even though the upstream region of $l s c B$ is sufficient to promote the expression of $l s c$, the expression level is enhanced by the presence 48-bp N-terminus of $l s c B$.

\section{Analysis of native gene expression of IscA in $P$. syringae pathovars}

Lack of expression of $l s c A$ had been shown before in P. syringae pv. glycinea PG4180 [10]. However, this has not been experimentally proven for other $P$. syringae pathovars. Consequently, possible expression patterns of $l s c A$ variants were also analyzed in the three $P$. syringae pathovars pv. phaseolicola 1448A, pv. syringae B728a and pv. tomato DC3000 using cDNA synthesis and PCR. No amplicon was detected in any of the four strains as shown in Figure 6 indicating that none of the $l s c A$ variants are expressed. The specificity of the primers was demonstrated by amplifying the $l s c A$ genes from corresponding genomic

Table 1 Proteins identified by MALDI-TOF analysis

\begin{tabular}{|c|c|c|c|c|c|c|}
\hline $\begin{array}{l}\text { NCBI accession } \\
\text { number/gi }\end{array}$ & Protein description & $\begin{array}{l}\text { Predicted molecular } \\
\text { mass (Da) }\end{array}$ & Significant hit & MASCOT score & Peptides matched & Sequence coverage (\%) \\
\hline 13936820 & LscB & 47,603 & LscB & 101 & 10 & 31 \\
\hline 3914944 & $\mathrm{LscB}_{\cup p N} \mathrm{~A}$ & 47,621 & LscA & 110 & 12 & 33 \\
\hline 416026576 & $\mathrm{LscB}_{\cup p} \mathrm{~A}$ & 45,844 & LscA & 110 & 8 & 19 \\
\hline
\end{tabular}




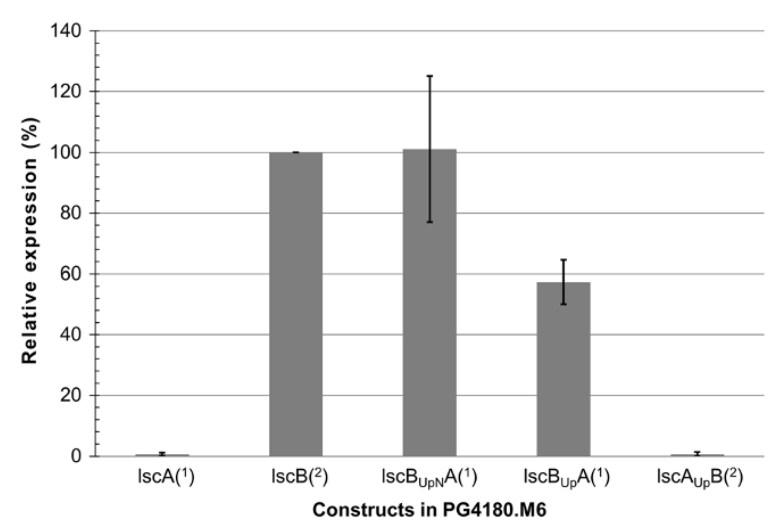

Figure 5 Quantitative expression of different Isc genes and constructs in dependence of $I \mathbf{s} \boldsymbol{C B}$. IsCB $B_{\cup p N} A$ shows similar levels of expression as $I s C B$ while $I s C B \cup p$, which does not contain the first $48 \mathrm{bp}$ of IsCB ORF, has lower expression. IsCA and $I s C A \cup p$ were not seen to be

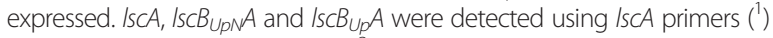
while the rest using $I s C B$ primers $\left({ }^{2}\right)$. The data represent the mean relative expression of 3 replicates \pm standard deviations. Data were normalized to the highest expression value of $I s c B$, which was set to $100 \%$.

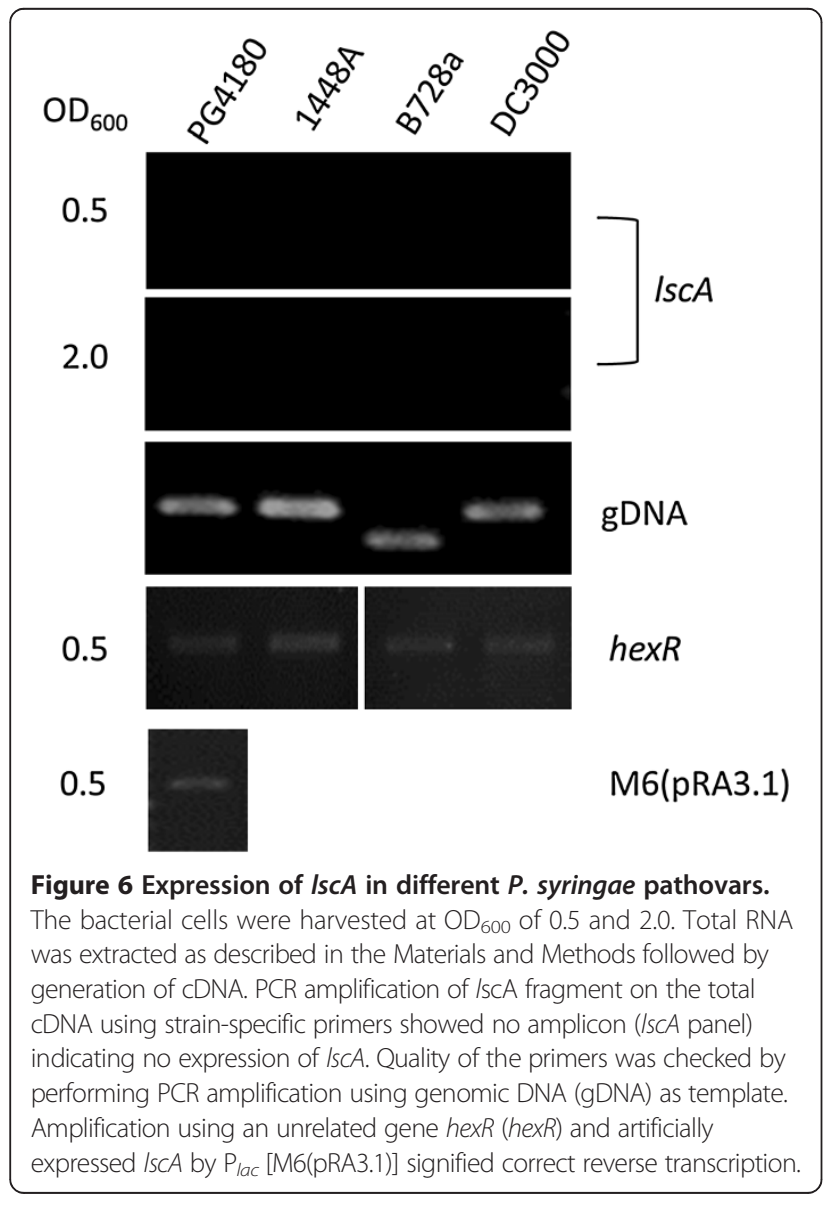

DNA, all of which gave amplicons of the expected sizes. The accuracy of reverse transcription was checked by amplifying a cDNA of a PG4180.M6 transformant carrying a recombinant $l s c A$ gene under the control of $\mathrm{P}_{\text {lac }}$, where $l s c A$ is known to be expressed [10]. Successful cDNA synthesis of total mRNA was also demonstrated by PCR amplifying the cDNA derived from the mRNA of the hexR gene, a hexose metabolism regulator [25]. Gene hex $R$ gave an amplicon of expected size (Figure 6) indicating correct cDNA synthesis.

\section{Discussion}

Genomic co-existence of three highly conserved genes coding for levansucrase is a feature unique to the plant pathogen $P$. syringae despite the fact that numerous other bacterial species harbor just a single copy of this gene in their genomes. Artificial expression of $l s c A$ from $P$. syringae under the control of the $\mathrm{P}_{\text {lac }}$ had been shown previously [10]. The same study also showed that $l s c A$ could not be expressed under its own promoter. Major differences between $l s c A$ and the natively expressed genes $l s c B$ and $l s c C$ are not found in the coding sequences but in their upstream DNA regions. The upstream regions of $l s c B$ and $l s c C$ represent a possible PAPE [24]. We previously hypothesized that this PAPE might harbor regulatory sites required for expression of levansucrase and general sugar metabolism in P. syringae. Herein, the PAPE of $l s c B$ was fused to the coding sequence of $l s c A$ and thus proven for its transcriptional activity in $P$. syringae.

The nucleotide sequence of the predicted PAPE consists of two parts, the upstream region of $l s c B$ and the first 48-bp coding for the N-terminus of LscB. The importance of these 48-bp of the ORF for the expression was tested by generating fusion constructs of the upstream region and $l s c A$ with or without these coding nucleotides. Transformants carrying either of the two fusion constructs produced levan similar to the PG4180.M6 mutant complemented with $l s c B$. Western blotting, zymographic detection, and qRT-PCR analyses confirmed these results but also allowed a more detailed view; native $l s c B$ and the $l s c B_{U p N} A$ fusion had similar mRNA expression levels while that of the fusion $l s c B_{U p} A$, which lacked the 48-bp of N-terminal LscB-coding region, had less. Consequently, one might speculate that although the -450 bp upstream DNA region of $l s c B$, which includes the TSS as determined in this study, is sufficient for expression of $l s c A$, the first 48-bp of the $l s c B$ ORF increase the level of its expression. Since our respective results of Western blotting and zymographic detection of Lsc activity were indistinguishable from each other, it could be concluded that the N-terminus of LscB might not be involved in altering of enzymatic activities.

A peculiar observation was the electrophoretic migration of the individual proteins or fusion proteins in polyacrylamide gels. The observed faster migration of $\mathrm{LscB}_{\mathrm{UpN}} \mathrm{A}$ 
as compared to LscB under denaturing conditions could potentially be attributed to the apparent mass shift for two proteins with nearly identical molecular masses as described earlier [26]. Interestingly, the migration of $\mathrm{LscB}_{\mathrm{UpN}} \mathrm{A}$ was significantly slower than that of LscB under native conditions. This finding might demonstrate that modest changes in the protein's surface charge might result in significant alterations of electrophoretic mobility $[22,27,28]$.

Although the different migration rates of the proteins or fusion proteins under native or denaturing conditions suggested that the synthesized proteins were indeed different from each other, a MALDI-TOF analysis of each of the proteins was conducted using protein samples from zymograms. The produced levan surrounding the proteins did not seem to impact mass spectrometric analysis. The MASCOT score for each of the identified proteins was above the significance threshold of 100 . The sample from the PG4180.M6(lscB) sample gave LscB from $P$. syringae pv. phaseolicola 1448A as the first significant match which was in line with the high homology of the respective genes in the close relatives pv. glycinea and pv. phaseolicola [24]. The sample from PG4180.M6(lscB $\left.\mathrm{Up}_{\mathrm{UP}} \mathrm{A}\right)$ which should synthesize only LscA gave the first significant match as LscA from $P$. syringae pv. glycinea race 4 strain. This proved that the $l s c B_{U p} A$ fusion actually synthesized an active LscA and confirmed earlier findings that artificial expression of LscA of PG4180 leads to levan formation [10]. Although the majority of obtained peptides for the sample representing $\mathrm{LscB}_{\mathrm{UpN}} \mathrm{A}$ were LscA-borne as expected, the unique $\mathrm{N}$-terminal 2,122-Da peptide NSPLASMSNINYAPTIWSR could be detected. This peptide is a consequence of the presence of the NheI restriction site coding for the amino acid residues alanine and serine. Oxidation of methionine, which was chosen as a variable modification parameter, added another 16 Da to the peptide mass which subsequently increased the mass of the NSPLASMSNINYAPTIWSR fragment to 2,138 Da. This mass was exactly the same as the mass of a recovered peptide which did not find a match during the NCBI search since the respective fusion peptide is not present in the database. Thus, the synthesis of the $\mathrm{LscB}_{\mathrm{UpN}} \mathrm{A}$ fusion protein could also be proven.

The majority of previous LscA-related studies have been performed with $P$. syringae pv. glycinea PG4180 $[9,10,23,24]$. However, thus far, there was no evidence for a lack of $l s c A$ expression in other pathovars of $P$. syringae. Since the genomes of $P$. syringae pv. phaseolicola $1448 \mathrm{~A}$, pv. syringae B728a and pv. tomato DC3000 are fully sequenced [19-21], template-specific oligonucleotide primers for cDNA-based mRNA detection could be designed. Although mRNA samples were extracted during different growth stages, namely, early-logarithmic and late-logarithmic phase, no amplicons could be detected in any of the strains suggesting that $l s c A$ variants were not expressed. PCR amplification, using respective genomic DNA as template, proved that the primers were binding correctly. An independent gene, hexR, coding for a conserved hexose metabolism regulator protein HexR, was chosen to see if the total mRNA had been reverse transcribed correctly [25]. This PCR amplification gave correct sized amplicon of 880-bp for all the four strains demonstrating the accuracy of the used method. PCR amplification was also performed on the cDNA obtained from mRNA samples of PG4180.M6 containing lscA under the control of $\mathrm{P}_{\text {lac }}$. This experiment gave the same-sized amplicon as for genomic DNA again proving the accuracy of the method.

In summary, we propose that $l s c A$ could be an ancestral Lsc variant in $P$. syringae as suggested by Srivastava et al. [24]. During evolution, the inactive promoter perhaps did not allow expression of $l s c A$ after this gene had potentially been introduced to an ancestral $P$. syringae. An evolutionary gene duplication of $l s c A$ followed by an insertion of a prophage-borne PAPE might have led to a new $l s c$ variant, i.e. $l s c B$ which in turn got duplicated yielding $l s c C$ or vice-versa. As a result of this evolutionary process, two functional and expressed $l s c$ genes emerged in the plant pathogen, for which utilization of sucrose, and perhaps levan formation, might be particularly important. The advantage of an additional in planta fitness-increasing and possibly virulence-promoting factor [29] could have helped this organism to selectively establish itself as a potent plant pathogen. As a consequence of this hypothesis, one could speculate on a loss of the supposedly nonexpressed $l s c A$ during further evolutionary steps, a phenomenon also previously hypothesized by Smits et al. [30].

\section{Conclusions}

The differential expression of levansucrases in P. syringae was long known, but not tested. In this study, we have potentially solved the previously unexplainable phenomenon that $P$. syringae is the only organism possessing multiple levansucrase-encoding genes. We demonstrated the importance of the upstream region as well as the N-terminus of $l s c B / C$ required for the expression of Lsc in P. syringae. The upstream region of $l s c A$ does not seem to promote $l s c$ expression. With careful controls, herein we also demonstrated that $l s c A$ is not expressed in other P. syringae pathovars.

\section{Methods}

\section{Bacterial strains, plasmids and growth conditions}

Bacterial strains, plasmids and oligonucleotides used in this study are listed in Tables 2 and 3. E. coli DH5 $\alpha$ was used as the cloning host [31] and grown in Lysogeny Broth (LB) medium at $37^{\circ} \mathrm{C}$. P. syringae cultures were grown in $\mathrm{HSC}$ medium $\left(0.8 \mathrm{mM} \mathrm{MgSO} 4.7 \mathrm{H}_{2} \mathrm{O}, 30 \mathrm{mM}\right.$ $\mathrm{KH}_{2} \mathrm{PO}_{4}, 16 \mathrm{mM} \mathrm{K} \mathrm{HPO}_{4}, 2 \mathrm{mM} \mathrm{KNO}, 20 \mu \mathrm{M} \mathrm{FeCl}_{3}$, $19 \mathrm{mM} \mathrm{NH}_{4} \mathrm{Cl}, 100 \mathrm{mM}$ glucose) [32] at $18^{\circ} \mathrm{C}$. Bacterial 
Table 2 Bacterial strains and plasmids used in this study

\begin{tabular}{|c|c|c|}
\hline Strain & Description & Reference or source \\
\hline \multicolumn{3}{|l|}{ Pseudomonas syringae } \\
\hline pv. glycinea PG4180 & Wild type, levan+ & R. Mitchell \\
\hline pv. phaseolicola 1448A & Wild type, levan+ & [33] \\
\hline pv. syringae B728a & Wild type, levan+ & {$[34]$} \\
\hline pv. tomato DC3000 & Wild type, levan+ & D. Cuppels \\
\hline \multicolumn{3}{|c|}{ Pseudomonas syringae pv. glycinea PG4180 } \\
\hline PG4180.M6 & $\mathrm{Sp}^{r}, \mathrm{Gm}^{\mathrm{r}}, \mathrm{IsCB}$ IscC mutant of PG4180, levan- & {$[10]$} \\
\hline PG4180.M6(pRA3.1) & $\begin{array}{l}\mathrm{Sp}^{r}, \mathrm{Gm}^{\mathrm{r}}, \mathrm{TC}^{\mathrm{r}}, I_{s c B} \mathrm{IscC} \text { mutant of PG4180, containing IscA under control of } \\
\mathrm{P}_{\text {lac }} \text { on } 3.1-\mathrm{kb} \text { Pstl fragment in pRK415 }\end{array}$ & {$[10]$} \\
\hline \multicolumn{3}{|l|}{ Escherichia coli } \\
\hline $\mathrm{DH} 5 \mathrm{a}$ & supE44 DlacU169 (F80 lacZDM15) hsdR17 recA1 endA1 gyrA96 thi-1 relA1 & {$[31]$} \\
\hline \multicolumn{3}{|l|}{ Plasmids } \\
\hline pRK2013 & $\mathrm{Km}^{r}$, helper plasmid & [35] \\
\hline pLB7.2 & $A p^{r}$, contains $I s c B$ on 7.2-kb EcoRV insert & [10] \\
\hline pBBR1MCS & $\mathrm{Cm}^{r}$, broad-host-range cloning vector & {$[36]$} \\
\hline PBBR1MCS-3 & $T c^{r}$, broad-host-range cloning vector & [36] \\
\hline pBBR3-500-IscB & $T C^{r}$, IsCB gene with $-500-b p$ upstream sequence in pBBR1MCS-3 & [24] \\
\hline pBBR3(IscA) & $T C^{r}$, IsCA gene containing insert from pRA3.1 in PBBR1MCS-3 not under control of $\mathrm{P}_{\text {lac }}$ & This study \\
\hline$p B B R 3\left(\mid s c B_{\cup p N} A\right)$ & $\begin{array}{l}T C^{r} \text {, fusion of 518-bp upstream region of } I s C B \text { (including first } 48 \text {-bp of coding region) } \\
\text { and IsCA (including start codon and downstream region) in pBBR1MCS-3 }\end{array}$ & This study \\
\hline $\operatorname{pBBR3}\left(\mid \operatorname{lsc}_{\cup \mathrm{up}} \mathrm{A}\right)$ & $\begin{array}{l}T c^{r} \text {, fusion construct of 470-bp upstream region of } I s c B \text { (without N-terminus) and IscA } \\
\text { (including start codon and downstream in pBBR1MCS-3 }\end{array}$ & This study \\
\hline pBBR3(IscA $\left.A_{\cup p} B\right)$ & $\begin{array}{l}\text { TCr, fusion of 550-bp upstream region of IsCA and IsCB (including start codon and } \\
\text { downstream region) in pBBR1MCS-3 }\end{array}$ & This study \\
\hline
\end{tabular}

Ap, Ampicillin; Cm, Chloramphenicol; Gm, Gentamycin; Km, Kanamycin; Sp, Spectinomycin; Tc, Tetracycline; ${ }^{r}$, resistant.

growth in liquid media was monitored by measuring the optical density at $600 \mathrm{~nm}\left(\mathrm{OD}_{600}\right)$ and harvested for (i) protein sampling at an $\mathrm{OD}_{600}$ of 2.0 or (ii) RNA extraction and cDNA synthesis at an $\mathrm{OD}_{600}$ of 0.5 and 2.0. Antibiotics were added to the media at the following concentrations $\left.(\mu \mathrm{g} \mathrm{ml})^{-1}\right)$ : ampicillin 50 ; tetracycline 25 , and chloramphenicol 25.

\section{Molecular genetic techniques}

Plasmid isolation, restriction enzyme digests, agarose and polyacrylamide gel electrophoreses, electroporation, PCR, and other routine molecular methods were performed using standard protocols [31]. Nested deletion analysis of the upstream region of $l s c B$ in plasmid pRB7.2 [10] was conducted using the Erase-a-Base kit (Promega, Madison, USA). For analysis of the $l s c$ upstream regions, PCR was used to generate products covering the respective regions (Table 3). PCR products of the lsc upstream regions were cloned in vectors pBBR1MCS or pBBR1MCS-3 [36].

\section{Determination of transcriptional start site}

Bacteria were incubated in $\mathrm{HSC}$ medium at $18^{\circ} \mathrm{C}$ to an $\mathrm{OD}_{600}$ of 0.5 and harvested by mixing $15 \mathrm{ml}$ of the culture with an equal volume of chilled killing buffer $(20 \mathrm{mM}$
Tris- $\mathrm{HCl}$ [pH7.5], $20 \mathrm{mM} \mathrm{NaN}_{3}$ ). This mixture was centrifuged at $4^{\circ} \mathrm{C}$ for $15 \mathrm{~min}$ at $3,220 \times$ g. Total RNA was isolated from the cell pellets by acid phenol/ chloroform extraction as described previously [37]. For primer extension analysis, $4 \mathrm{pmol}$ of ${ }^{32} \mathrm{P}$-labeled primer pe.BC.PG $150 \mathrm{bp}$ (Table 3) were annealed with $10 \mu \mathrm{g}$ of total RNA and reverse transcription was performed with M-MLV Reverse Transcriptase (Invitrogen, Karlsruhe, Germany). Nucleotide sequencing using $5 \mu \mathrm{g}$ of plasmid pLB7.2 (Table 2) and primer pe.BC.PG 150 bp was done with the Sequenase Version 2.0 DNA Sequencing Kit (USB, Cleveland, USA) according to the manufacturer's recommendation. The extension product and sequencing reaction were resolved on a $6 \%$ polyacrylamide sequencing gel. Signal detection was performed using a FLA-3000 phosphorimager (Raytest, Straubenhardt, Germany) according to the manufacturer's recommendations.

\section{Generation of fusion constructs}

All genes or DNA fragments were obtained by PCR amplification unless otherwise stated. All restriction enzymes used were obtained from Thermo Fisher Scientific Biosciences (St. Leon Rot, Germany). The nucleotide sequencing was done by Eurofins MWG Operon (Ebersberg, Germany). 
Table 3 Oligonucleotide primers used in this study

\begin{tabular}{|c|c|}
\hline Oligonucleotides & Nucleotide sequence $\left(5^{\prime}-3^{\prime}\right)^{\dagger}$ \\
\hline pe.BC.PG $150 \mathrm{bp}$ & GTCACCCATGCGGGCCAGCAG \\
\hline IscB_UpN_f & CCCAAGCTTCGATTGCAAGCTGATACACGTACC \\
\hline IscB_UpN_r & TAGGCTAGCTAGAGGACTATITTGAG \\
\hline IscA_ORF_f & CTAGCTAGCATGAGTAACATCAATTAC \\
\hline IscA_ORF_r & CCCAAGCTTCGGACGTCATCCTGATCGACAC \\
\hline IscB_Up_r & TAGGCTAGCAATTGATACCTITAAATAGCTITGGGAG \\
\hline IscA_Up_f & CGGGATCCAGCAAAGCGCTGTAAAACAGG \\
\hline IscA_Up_r & CTACTAGCTAGCGATGATGTCCTITATTGGCGC \\
\hline IscB_ORF_f & GCTCTAGATGTCCACTAGCAGCTCTGCTGTAA \\
\hline IscB_ORF_r & CCCAAGCTITCAGTATTACGGATACGATGAGC \\
\hline IscA_gly_f & TAAGCCCGGATTTTCCGGTC \\
\hline IscA_gly_r & TACTGTATGCGTGCCGCGTT \\
\hline IscA_pha_f & TCACGCTGACGGCTGACCGC \\
\hline IscA_pha_r & GCCTACTGTATGCGTGCCGCG \\
\hline IscA_syr_f & TCACGCTGACAGCTGATCGC \\
\hline IscA_syr_r & ACCAACGGTATGCGTACCGC \\
\hline IscA_tom_f & ATCACCCTGACAGCCGACCG \\
\hline IscA_tom_r & ACCGACAGTATGTGAACCCCGCT \\
\hline IsCA_f_RT & ATGAGTAACATCAATTACGCACCC \\
\hline IsCA_r_RT & TACTTTGGCAATTGCCGCAC \\
\hline IscB_f_RT & CTCTGCTGTAAGCCAGCTCAA \\
\hline IscB_r_RT & CGGGTGTGACGCAGGTGTAA \\
\hline gyrA_fw & CGAAGAGCTGGAAGTGATCC \\
\hline gryA_rv & GACGCTGAGCCTGATAGACC \\
\hline hexR_fw & ATGGACCGCGTAAGAAAC \\
\hline hexR_rv & TCAGCCTTGATCCTCGATCGG \\
\hline
\end{tabular}

${ }^{\dagger}$ Restriction sites in the primers are in italics: GAGCTC - Sacl, AAGCTT - Hindlll, GCTAGC - Nhel, GGATCC - BamHI, TCTAGA - Xbal.

Generation of $l s c B_{U p N} A$ and $l s c B_{U p} A$ : The sequences of the 518-bp PAPE and the 470-bp $l s c B$ upstream region without the 48-bp coding sequence, respectively, were ligated to the $\mathrm{N}$-terminus of the 1,748-bp $l s c A$ fragment using T4 DNA Ligase (Thermo Fisher Scientific Biosciences) after treating the DNA with restriction enzyme NheI. The ligation products were then treated with HindIII, analysed by agarose gel electrophoresis, and the bands corresponding to the fusion products $(2,284$ and 2,224 bp, respectively) were purified from the gel using GeneJET Gel Extraction kit (Thermo Fisher Scientific Biosciences). The purified fusion products were ligated into pBluescriptKS(II) using HindIII in such a way that the fusion products were under control of the vector-borne lac promoter $\left(\mathrm{P}_{l a c}\right)$. Formation of levan on LB agar containing 5\% sucrose indicated a functional $l s c A$ gene driven by the $\mathrm{P}_{l a c}$. The PAPE and $l s c B$ upstream regions were sequenced to exclude any possibility of mutations. The fusion products were then cloned into the broad host-range vector pBBR1MCS using HindII in order to ligate them in opposite orientation to the $\mathrm{P}_{l a c}$ and then cloned into pBBR1MCS-3 using restriction enzymes PstI and XhoI to keep the same opposite orientation with respect to $\mathrm{P}_{\text {lac }}$ as in case of pBBR1MCS. The constructs were introduced into mutant PG4180.M6 via electroporation.

Generation of $l s c A_{U p} B$ : A similar cloning strategy was used to generate the $l s c A_{U p} B$ construct. The $\mathrm{C}$-terminus of the 550-bp PCR-amplified $l s c A$ upstream region and the $\mathrm{N}$-terminus of the 1,704-bp PCR-amplified ORF $l s c B$ were ligated using a combination of restriction enzymes $X b a \mathrm{I}$ and NheI which generate compatible DNA ends. This ligation product was treated with endonucleases BamHI and HindIII and subsequently ligated into pBluescript-SK $(-)$. The constructs were cloned into pBBR1MCS using restriction enzymes BamHI and HindII in order to ligate them in opposite orientation to the $\mathrm{P}_{l a c}$ and then into pBBR1MCS-3 using restriction enzymes using $X b a \mathrm{I}$ and ApaI to keep the same opposite orientation with respect to $\mathrm{P}_{l a c}$ as in case of pBBR1MCS.

\section{Immunological and enzymatic detection of Lsc}

Total proteins from PG4180.M6 and PG4180.M6 transformants harboring the $l s c$ fusion constructs were obtained as described previously [23]. For immunological detection of the Lsc enzyme, total proteins were separated by $10 \%$ SDS-PAGE and Western blot experiments were performed with total protein fractions using polyclonal antibodies raised against purified Lsc as reported earlier [10]. Zymographic detection of Lsc was done as described previously by separating the total proteins by $10 \%$ native-PAGE and incubating the gels in 5\% sucrose solution [10]. Bacterial cells grown on mannitol-glutamate agar plates with $1.5 \%$ agar and $5 \%$ sucrose were used for the qualitative visualization of Lsc activity, which led to levan formation in form of a mucoid, dome-shaped colony morphology. Lsc activity was quantified by measuring the amount of glucose liberated during incubation with sucrose using the Gluco-quant Glucose/HK assay kit (Roche Diagnostics, Mannheim, Germany) at an absorbance of $340 \mathrm{~nm}$. One unit of Lsc activity corresponded to the amount of enzyme which liberates $1 \mu \mathrm{mol}$ glucose per minute from sucrose. The experiments were repeated threefold and mean values were expressed as the quantity of glucose release.

\section{MALDI-TOF mass spectrometric analysis}

Total proteins were separated using 10\% native-PAGE and incubated in 5\% sucrose solution overnight [10]. As soon as in-gel levan formation became apparent, the corresponding bands were cut out from the gel and subjected to an in-gel proteolytic cleavage using modified porcine trypsin (Promega, Madison, WI) as adapted from 
previous reports [38-40]. Trypsin digestion was carried out for $12-16 \mathrm{~h}$ at $37^{\circ} \mathrm{C}$, and peptide samples were directly used for MALDI-TOF MS exposure using an Autoflex II TOF/TOF mass spectrometer (Bruker Daltonics, Bremen, Germany) equipped with a $337 \mathrm{~nm}$ nitrogen laser and operated with FlexControl 3.0 software. The matrix used was $1 \mathrm{mg} \mathrm{ml}^{-1}$ of a-cyano-4-hydroxycinnamic acid (HCCA; Bruker Daltonics) disolved in acetone and mixed with two volumes of ethanol. Peptide samples were acidified with $0.5 \%$ TFA in a ratio of $1: 1(\mathrm{v} / \mathrm{v})$ and mixed with the HCCA solution in a ratio of $1: 1(\mathrm{v} / \mathrm{v})$. Samples of $0.5 \mu \mathrm{L}$ were spotted and air-dried on MTB AnchorChip targets with an anchor diameter of $600 \mu \mathrm{m}$ (Bruker Daltonics). Spots were twice rinsed with $2 \mu \mathrm{L}$ of $10 \mathrm{mM}$ monobasic ammonium phosphate solution for $\sim 5 \mathrm{~s}$, dried, and exposed to MALDI-TOF MS in positive-ion reflection mode with the laser offset set to $67 \%+/-15 \%$ and an acquisition range of $800-4,000 \mathrm{Da}$. A signal-to-noise ratio of 6 was applied for peak identification using the Mascot search engine [41] from Biotools software 3.1. Mass lists were compared with NCBI databases and the Mascot score probability set for $\mathrm{p}<0.05$. Peptide sequence analyses was done using the ExPASy bioinformatics resource portal [42].

\section{Analysis of Isc gene expression by quantitative Reverse Transcriptase polymerase chain reaction (qRT-PCR)}

Total RNA was isolated by acid phenol/chloroform extraction as described previously [11]. The yield and the purity of RNA were determined by measuring absorption at $260 \mathrm{~nm}$. Total mRNA samples were treated with TURBO DNA-free (Applied Biosystems, Darmstadt, Germany) to remove remaining traces of genomic DNA as described by the manufacturer's recommendation. SYBR-green based qRT-PCR was performed with 5 ng RNA template and $100 \mu \mathrm{M}$ primer with QuantiTect SYBR Green one-step RT-PCR Kit (Qiagen, Hilden, Germany) according to the manufacturer's instructions. The thermocycler program comprised an initial step of $95^{\circ} \mathrm{C}$ for 15 min followed by 40 cycles of $95^{\circ} \mathrm{C}$ for $30 \mathrm{~s}, 58^{\circ} \mathrm{C}$ for $30 \mathrm{~s}, 72^{\circ} \mathrm{C}$ for $30 \mathrm{~s}$. Reactions were performed with biological triplicates in a Mastercycler ep realplex2 real-time PCR system (Eppendorf, Hamburg, Germany) as described by the manufacturer using their universal program. Reactions with no addition of reverse transcriptase served as negative control and proved the absence of DNA contamination. Specificity of amplification was assessed by analyzing the melting curve of the amplification product. Primers to amplify $l s c B$ were used for constructs $l s c B$ and $l s c A_{U p} B$ while primers to amplify $l s c A$ were used for constructs $l s c A$, $l s c B_{U p N} A$ and $l s c B_{U p} A$. All the results were normalized to amplification of the cDNA of gyrA (PSPPH3667) as described previously [43].

\section{Analysis of IscA gene expression by Reverse-Transcriptase polymerase chain reaction (RT-PCR)}

Template-specific primers were designed for the respective $l s c A$ variants of $P$. syringae pv. glycinea PG4180, pv. phaseolicola 1448A, pv. syringae B728a, and pv. tomato DC3000. Bacterial cells were grown in HSC medium and harvested at an $\mathrm{OD}_{600}$ of 0.5 as well as 2.0. RNA was extracted by acid phenol/chloroform extraction method [11]. An RT-PCR was performed on total mRNA using RevertAid First Strand cDNA Synthesis Kit (Fermentas) as recommended by the manufacturer. The strain-specific $l s c A$ primers were used to check for presence of an $l s c A$ mRNA by PCR using cDNA as template. Regular PCR with the same primer-pairs and genomic DNA as template were used as controls. The thermocycler program was as follows: 1 cycle of $95^{\circ} \mathrm{C}$ for $90 \mathrm{~s} ; 25$ cycles of $95^{\circ} \mathrm{C}$ for $15 \mathrm{~s}$, $66^{\circ} \mathrm{C}$ for $15 \mathrm{~s}, 72^{\circ} \mathrm{C}$ for $30 \mathrm{~s} ; 1$ cycle of $72^{\circ} \mathrm{C}$ for $5 \mathrm{~min}$. The results were analyzed by $1 \%$ agarose gel electrophoresis.

\section{Bioinformatics analyses}

Vector NTI Advance 10.1.1 (Life Technologies, California, USA) was used for the nucleotide, amino acid sequence alignments, as well as for generating genetic maps. BLAST$\mathrm{N}$ and BLAST-P programs were used for online sequence analyses [44]. The website www.pseudomonas.com was consulted for the determination of $P$. syringae gene orthologs and paralogs [45].

\section{Abbreviations}

Lsc: Levansucrase; MALDI-TOF: Matrix-assisted laser desorption/ionization-time of flight; PAPE: Phage-associated promoter element; PG4180: Pseudomonas syringae pv. glycinea PG4180.

\section{Competing interests}

All authors of the study (SK, ASr, DP, ASt and MU) declare that there are no competing interests (whether political, personal, religious, ideological, academic, intellectual or commercial) or any other activities influencing the work.

\section{Authors' contributions}

SK generated the fusion constructs, performed the levan formation, Western blot, zymogram, RT-PCR and qRT-PCR assays; ASr determined the transcriptional start site; DP generated and analysed a fusion construct; ASt conducted the MALDI-TOF data acquisition and analysis; MU coordinated the study; SK and $\mathrm{MU}$ prepared and revised the manuscript draft. All authors contributed to the preparation and approval of the final manuscript.

\section{Authors' information \\ SK - Department of Molecular Microbiology, Molecular Life Sciences Research Center, Jacobs University Bremen, Germany; ASr - Current Address: Department of Experimental Limnology, Leibniz-Institute of Freshwater Ecology and Inland Fisheries, Stechlin, Germany; DP - Department of Biochemical Engineering, Molecular Life Sciences Research Center, Jacobs University Bremen, Germany; ASt - Department of Molecular Microbiology, Molecular Life Sciences Research Center, Jacobs University Bremen, Germany; MU - Department of Molecular Microbiology, Molecular Life Sciences Research Center, Jacobs University Bremen, Germany.}

\section{Acknowledgements}

We thank Helge Weingart for his helpful comments and Ramesh Mavathur for his help with Sanger sequencing. This study was supported by the Deutsche Forschungsgemeinschaft (UL-169/5-1). 


\section{Author details}

${ }^{1}$ Molecular Life Sciences Research Center, Jacobs University Bremen, Campus Ring 1, Bremen 28759, Germany. ${ }^{2}$ Current Address: Department of Experimental Limnology, Leibniz-Institute of Freshwater Ecology and Inland Fisheries, Alte Fischerhuette 2, Stechlin 16775, Germany.

Received: 22 January 2014 Accepted: 19 March 2014

Published: 27 March 2014

\section{References}

1. Mansfield J, Genin S, Magori S, Citovsky V, Sriariyanum M, Ronald P, Dow M, Verdier V, Beer SV, Machado MA, Toth I, Salmond G, Foster GD: Top 10 plant pathogenic bacteria in molecular plant pathology. Mol Plant Pathol 2012, 13:614-629.

2. Young J, Saddler G, Takikawa Y: Names of plant pathogenic bacteria, 1864-1995. Rev Plant Pathol 1996, 75:721-736.

3. Kvitko BH, Park DH, Velásquez AC, Wei C-F, Russell AB, Martin GB, Schneider DJ, Collmer A: Deletions in the repertoire of Pseudomonas syringae pv. tomato DC3000 type III Secretion effector genes reveal functional overlap among effectors. PLoS Pathog 2009, 5:e100388.

4. Zhang J, Li W, Xiang T, Liu Z, Laluk K, Ding X, Zou Y, Gao M, Zhang X, Chen S, Mengiste T, Zhang $Y$, Zhou J-M: Receptor-like cytoplasmic kinases integrate signaling from multiple plant immune receptors and are targeted by a Pseudomonas syringae effector. Cell Host Microbe 2010, 7:290-301.

5. Huynh T, Dahlbeck D, Staskawicz B: Bacterial blight of soybean: regulation of a pathogen gene determining host cultivar specificity. Science 1989, 245:1374-1377.

6. Denny TP: Involvement of bacterial polysaccharides in plant pathogenesis. Annu Rev Phytopathol 1995, 33:173-197.

7. Osman SF, Fett WF, Fishman ML: Exopolysaccharides of the phytopathogen Pseudomonas syringae pv. glycinea. J Bacteriol 1986, 166:66-71.

8. Gross M, Rudolph K: Studies on the extracellular polysaccharides (EPS) produced in vitro by Pseudomonas phaseolicola I. Indications for a polysaccharide resembling alginic acid in seven $P$. syringae pathovars. J Phytopathol 1987, 118:276-287.

9. Hettwer U, Jaeckel FR, Boch J, Meyer M, Rudolph K, Ullrich MS: Cloning, nucleotide sequence, and expression in Escherichia coli of levansucrase genes from the plant pathogens Pseudomonas syringae pv. glycinea and P. syringae pv. phaseolicola. Appl Env Microbiol 1998, 64:3180-3187.

10. Li H, Ullrich MS: Characterization and mutational analysis of three allelic Isc genes encoding levansucrase in Pseudomonas syringae. J Bacteriol 2001, 183:3282-3292.

11. Schenk A, Berger M, Keith LM, Bender CL, Muskhelishvili G, Ullrich MS: The algT gene of Pseudomonas syringae pv. glycinea and new insights into the transcriptional organization of the algT-muc gene cluster. J Bacteriol 2006, 188:8013-8021.

12. Sohn KH, Jones JDG, Studholme DJ: Draft genome sequence of Pseudomonas syringae pathovar syringae strain FF5, causal agent of stem tip dieback disease on ornamental pear. J Bacteriol 2012, 194:3733-3734.

13. Liu H, Qiu H, Zhao W, Cui Z, Ibrahim M, Jin G, Li B, Zhu B, Xie GL: Genome sequence of the plant pathogen Pseudomonas syringae pv. panici LMG 2367. J Bacteriol 2012, 194:5693-5694.

14. Almeida NF, Yan S, Lindeberg M, Studholme DJ, Schneider DJ, Condon B, Liu H, Viana CJ, Warren A, Evans C, Kemen E, Maclean D, Angot A, Martin GB, Jones JD, Collmer A, Setubal JC, Vinatzer BA: A draft genome sequence of Pseudomonas syringae pv. tomato T1 reveals a type III effector repertoire significantly divergent from that of Pseudomonas syringae pv. tomato DC3000. Mol Plant Microbe Interact 2009, 22:52-62.

15. Studholme DJ, Ibanez SG, MacLean D, Dangl JL, Chang JH, Rathjen JP: A draft genome sequence and functional screen reveals the repertoire of type III secreted proteins of Pseudomonas syringae pathovar tabaci 11528. BMC Genomics 2009, 10:395.

16. Green S, Studholme DJ, Laue BE, Dorati F, Lovell H, Arnold D, Cottrell JE, Bridgett S, Blaxter M, Huitema E, Thwaites R, Sharp PM, Jackson RW, Kamoun S: Comparative genome analysis provides insights into the evolution and adaptation of Pseudomonas syringae pv. aesculi on Aesculus hippocastanum. PloS One 2010, 5:e10224.

17. Qi M, Wang D, Bradley CA, Zhao Y: Genome sequence analyses of Pseudomonas savastanoi pv. glycinea and subtractive hybridization-based comparative genomics with nine pseudomonads. PloS One 2011, 6:e16451.
18. Marcelletti S, Ferrante P, Petriccione M, Firrao G, Scortichini M: Pseudomonas syringae pv. actinidiae draft genomes comparison reveal strain-specific features involved in adaptation and virulence to Actinidia species. PloS One 2011, 6:e27297.

19. Buell CR, Joardar V, Lindeberg M, Selengut J, Paulsen IT, Gwinn ML, Dodson RJ, Deboy RT, Durkin AS, Kolonay JF, Madupu R, Daugherty S, Brinkac L, Beanan MJ, Haft DH, Nelson WC, Davidsen T, Zafar N, Zhou L, Liu J, Yuan Q, Khouri H, Fedorova N, Tran B, Russell D, Berry K, Utterback T, Aken SEV, Feldblyum TV, D'Ascenzo M, et al. The complete genome sequence of the Arabidopsis and tomato pathogen Pseudomonas syringae pv. tomato DC3000. Proc Nat Acad Sci USA 2003, 100:10181-10186.

20. Joardar V, Lindeberg M, Jackson RW, Selengut J, Dodson R, Brinkac LM, Daugherty SC, DeBoy R, Durkin AS, Giglio MG, Madupu R, Nelson WC, Rosovitz MJ, Sullivan S, Crabtree J, Creasy T, Davidsen T, Haft DH, Zafar N, Zhou L, Halpin R, Holley T, Khouri H, Feldblyum T, White O, Fraser CM Chatterjee AK, Cartinhour S, Schneider DJ, Mansfield J, et al. Whole-genome sequence analysis of Pseudomonas syringae pv. phaseolicola 1448A reveals divergence among pathovars in genes involved in virulence and transposition. J Bacteriol 2005, 187:6488-6498.

21. Feil H, Feil WS, Chain P, Larimer F, DiBartolo G, Copeland A, Lykidis A, Trong S, Nolan M, Goltsman E, Thiel J, Malfatti S, Loper JE, Lapidus A, Detter JC, Land M, Richardson PM, Kyrpides NC, Ivanova N, Lindow SE: Comparison of the complete genome sequences of Pseudomonas syringae pv. syringae B728a and pv. tomato DC3000. Proc Natl Acad Sci USA 2005, 102:11064-11069.

22. Visnapuu T, Mäe A, Alamäe T: Hansenula polymorpha maltase gene promoter with sigma 70-like elements is feasible for Escherichia coli-based biotechnological applications: Expression of three genomic levansucrase genes of Pseudomonas syringae pv. tomato. Process Biochem 2008, 43:414-422.

23. Li H, Schenk A, Srivastava A, Zhurina D, Ullrich MS: Thermo-responsive expression and differential secretion of the extracellular enzyme levansucrase in the plant pathogenic bacterium Pseudomonas syringae pv. glycinea. FEMS Microbiol Lett 2006, 265:178-185.

24. Srivastava A, Al-Karablieh N, Khandekar S, Sharmin A, Weingart H, Ullrich MS: Genomic distribution and divergence of levansucrase-coding genes in Pseudomonas syringae. Genes 2012, 3:115-137.

25. Del Castillo T, Ramos JL, Rodríguez-Herva JJ, Fuhrer T, Sauer U, Duque E: Convergent peripheral pathways catalyze initial glucose catabolism in Pseudomonas putida: genomic and flux analysis. J Bacteriol 2007, 189:5142-5152.

26. Rickwood D, Hames BD: Gel Electrophoresis of Nucleic Acids: A Practical Approach. Oxford: IRL press; 1990

27. Schagger H, Cramer WA, Vonjagow G: Analysis of molecular masses and oligomeric states of protein complexes by blue native electrophoresis and isolation of membrane protein complexes by two-dimensional native electrophoresis. Anal Biochem 1994, 217:220-230.

28. Wittig I, Beckhaus T, Wumaier Z, Karas M, Schägger H: Mass estimation of native proteins by blue native electrophoresis. Mol Cell Proteomics MCP 2010, 9:2149-2161.

29. Geier G, Geider K: Characterization and influence on virulence of the levansucrase gene from the fireblight pathogen Erwinia amylovora. Physiol Mol Plant Pathol 1993, 42:387-404

30. Smits THM, Rezzonico F, Duffy B: Evolutionary insights from Erwinia amylovora genomics. J Biotechnol 2011, 155:34-39.

31. Sambrook J: Molecular Cloning: A Laboratory Manual, Third Edition. 3rd edition Cold Spring Harbour, New York: Cold Spring Harbor Laboratory Press; 2001.

32. Bender CL, Liyanage $H$, Palmer D, Ullrich M, Young S, Mitchell R: Characterization of the genes controlling the biosynthesis of the polyketide phytotoxin coronatine including conjugation between coronafacic and coronamic acid. Gene 1993, 133:31-38.

33. Teverson DM: Genetics of Pathogenicity and Resistance in the Halo-Blight Disease of Beans in Africa, Ph.D. thesis. United Kingdom: University of Birmingham, Birmingham; 1997

34. Loper J, Lindow S: Lack of evidence for in situ fluorescent pigment production by Pseudomonas syringae pv. syringae on bean leaf surfaces. Phytopathology 1987, 77:1449-1454.

35. Figurski DH, Helinski DR: Replication of an origin-containing derivative of plasmid RK2 dependent on a plasmid function provided in trans. Proc Natl Acad Sci USA 1979, 76:1648-1652.

36. Kovach ME, Elzer PH, Hill DS, Robertson GT, Farris MA, Roop RM 2nd, Peterson KM: Four new derivatives of the broad-host-range cloning 
vector pBBR1MCS, carrying different antibiotic-resistance cassettes. Gene 1995, 166:175-176.

37. Schenk $A$, Weingart $H$, Ullrich MS: Extraction of high-quality bacterial RNA from infected leaf tissue for bacterial in planta gene expression analysis by multiplexed fluorescent Northern hybridization. Mol Plant Pathol 2008, 9:227-235.

38. Shevchenko A, Tomas H, Havlis J, Olsen JV, Mann M: In-gel digestion for mass spectrometric characterization of proteins and proteomes. Nat Protoc 2006, 1:2856-2860.

39. Speicher KD, Kolbas O, Harper S, Speicher DW: Systematic analysis of peptide recoveries from in-gel digestions for protein identifications in proteome studies. J Biomol Tech JBT 2000, 11:74-86.

40. Granvogl B, Plöscher M, Eichacker LA: Sample preparation by in-gel digestion for mass spectrometry-based proteomics. Anal Bioanal Chem 2007, 389:991-1002.

41. Perkins DN, Pappin DJ, Creasy DM, Cottrell JS: Probability-based protein identification by searching sequence databases using mass spectrometry data. Electrophoresis 1999, 20:3551-3567.

42. Artimo P, Jonnalagedda M, Arnold K, Baratin D, Csardi G, de Castro E, Duvaud S, Flegel V, Fortier A, Gasteiger E, Grosdidier A, Hernandez C, loannidis V, Kuznetsov D, Liechti R, Moretti S, Mostaguir K, Redaschi N Rossier G, Xenarios I, Stockinger H: ExPASy: SIB bioinformatics resource portal. Nucleic Acids Res 2012, 40:W597-W603.

43. Vencato M, Tian F, Alfano JR, Buell CR, Cartinhour S, DeClerck GA, Guttman DS, Stavrinides J, Joardar V, Lindeberg M: Bioinformatics-enabled identification of the HrpL regulon and type III secretion system effector proteins of Pseudomonas syringae pv. phaseolicola 1448A. Mol Plant Microbe Interact 2006, 19:1193-1206.

44. Mount DW: Using the Basic Local Alignment Search Tool (BLAST). In Bioinformatics: Sequence and Genome Analysis. $2^{\text {nd }}$ edition. Cold Spring Har Protoc 2007, 7:pdb.top17.

45. Winsor GL, Lam DKW, Fleming L, Lo R, Whiteside MD, Yu NY, Hancock REW, Brinkman FSL: Pseudomonas Genome Database: improved comparative analysis and population genomics capability for Pseudomonas genomes. Nucleic Acids Res 2011, 39:D596-D600.

doi:10.1186/1471-2180-14-79

Cite this article as: Khandekar et al:: The conserved upstream region of IscB/C determines expression of different levansucrase genes in plant pathogen Pseudomonas syringae. BMC Microbiology 2014 14:79.

\section{Submit your next manuscript to BioMed Central and take full advantage of:}

- Convenient online submission

- Thorough peer review

- No space constraints or color figure charges

- Immediate publication on acceptance

- Inclusion in PubMed, CAS, Scopus and Google Scholar

- Research which is freely available for redistribution

Submit your manuscript at www.biomedcentral.com/submit
(O) Biomed Central 